This is an Open Access article licensed under the terms of the Creative Commons AttributionNonCommercial 3.0 Unported license (CC BY-NC) (www.karger.com/OA-license), applicable to the online version of the article only. Distribution permitted for non-commercial purposes only.

\title{
Therapeutic Effects of Hydrogen-Rich Solution on Aplastic Anemia in Vivo
}

\author{
Sanhu Zhao a, d, Ke Mei $^{a, e, f}$ Liren Qian ${ }^{b}$ Yanyong Yang ${ }^{a}$ Wen Liu ${ }^{a}$ Yijuan Huang ${ }^{a}$ \\ Chao Zhanga Xunjun Sunc Cong Liu ${ }^{a}$ Bailong Lia Fu Gao Jianming Cai ${ }^{a}$ Jin Nia \\ aDepartment of Radiation Medicine, Second Military Medical University, Shanghai, PR China; \\ bDepartment of Hematology, Navy General Hospital, Beijng, PR China; 'Department of Diving Medicine,

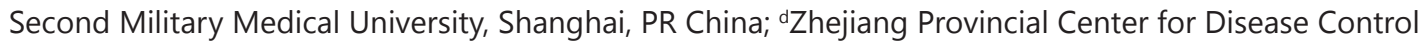 \\ and Prevention, Zhejiang, PR China; eDepartment of Radiology, Shanghai First People's Hospital, \\ Shanghai, PR China; fSanhu Zhao and Ke Mei contributed equally to this work
}

\section{Key Words}

Aplastic anemia $\cdot$ Hydrogen-rich solution - Peripheral blood $•$ Bone marrow $•$ Cytokine

\begin{abstract}
Background: Aplasitc anemia (AA) is a bone marrow failure syndrome characterized by an immune-mediated destruction of hematopoietic stem cells. Though clinical symptoms could be ameliorated by bone marrow transplantation and/or immunosuppressive therapy, frequent recurrence and especially evolution of clonal hematologic diseases remains problematic clinically. Cytokines such as interferon- $\gamma$ (INF- $\gamma$ ), tumor necrosis factor- $\alpha$ (TNF- $\alpha$ ) and interleukin-6 (IL-6) secreted by autologous T cells are closely related with the development of AA. Hydrogen-rich solution was reported to inhibit the levels of cytokines including INF- $\gamma$, TNF- $\alpha$ and IL- 6 in vivo in recent studies. This study was to investigate the potential therapeutic effects of hydrogen-rich solution on AA in vivo. Methods: AA model was determined in vivo by mice and body weights of the mice were used as the basic physiological index. Peripheral blood cells were calculated to evaluate the hematologic recovery degree. Bone marrow nucleated cells (BMNCs), tissue histology, as well as CFU-S and CFU-GM forming units were used to evaluate the recovery of bone marrow microenvironment. The ratio of $\mathrm{CD}^{+}{ }^{+}$and $\mathrm{CD}^{+}$ cells were examined along with cytokine levels in serum to determine the efficacy of $\mathrm{H}_{2}{ }^{-}$ rich solution on the affected immunological functions. Results: Body weight and number of peripheral blood cells were significantly improved for mice in the $\mathrm{H}_{2}$-rich solution treated groups as compared with those with AA. The number of BMNCs and CFÚs increased markedly and the bone marrow microenvironment was also improved significantly. The experimental group restrained the cell apoptosis, relieved hyperemia and accelerated tissue repair. The number of $\mathrm{CD}^{+}$and $\mathrm{CD}^{+}$cells as well as the ratio of CD4/CD8 increased to normal gradually, while the levels of TNF- $\alpha$, IFN- $\gamma$, and IL- 6 in serum decreased after $\mathrm{H}_{2}$-rich solution treatment. Conclusion: Our study firstly showed that hydrogen-rich solution accelerated the recovery of either hematological or immunological recovery on aplastic anemia mice. This finding suggests hydrogen-rich solution as a potential clinical therapeutic agent for AA.
\end{abstract}

Copyright (C) 2013 S. Karger AG, Basel

Dr. Jianming Cai and Dr. Jin Ni

Department of Radiation Medicine, Faculty of Naval Medicine, Second Military Medical University, Xiangyin Road, 200433, Shanghai (PR China)

Tel. +86-21-81871101, Fax +86-21-81871101

E-Mail cjm882003@yahoo.com.cn (Cai JM) and E-Mail nijin2006@yahoo.com.cn (Ni J) 


\section{Cellular Physiology and Biochemistry}

Cell Physiol Biochem 2013;32:549-560

Zhao/Mei/Qian et al. Hydrogen to Aplastic Anemia

\section{Introduction}

Aplastic anemia (AA) is characterized by bone marrow failure syndrome which includes severe deficiencies in whole peripheral blood cells and apoptosis of CD34 ${ }^{+}$cells which results in pancytopenia and hypocellular marrow [1]. Though the development of AA is unclear for the majority of acquired cases, the most favored hypothesis is that aplastic anemia might be an immune-mediated disease as a result of immune deficiency [2]. Autologous $\mathrm{T}$ cells, including $\mathrm{CD}^{+}$cytotoxic T cells, CD4+ Th1 cells, Th17 cells and Treg cells, play critical roles following the affected bone marrow hematopoietic progenitors [3]. CD8 ${ }^{+}$cytotoxic $\mathrm{T}$ cells are expanded and secrete pro-inflammatory cytokines such as IFN- $\gamma$ and TNF- $\alpha$,which induce apoptosis of CD34+ cells, in part through the Fas/FasL, TRAIL and p38MAPK signaling pathways [4]. $\mathrm{CD}^{+} \mathrm{T}$ cells mainly contribute to the pathogenesis of aplastic anemia while $\mathrm{CD}^{+}{ }^{+} \mathrm{T}$ cells may be even more crucial than $\mathrm{CD}^{+}$in autoimmunity. Immoderate production of inhibitory cytokines such as IFN- $\gamma$, TNF- $\alpha$ and IL-2 from T cells in AA patients suggests that Th1 polarization responses direct toxicity to autologous $\mathrm{CD} 34^{+}$cells [5]. Th17 cells could secret a large amount of IL-17A, which could coordinates tissue inflammation by expressing the pro-inflammatory cytokines such as IL-6, TNF- $\alpha$, which mediates tissue infiltration and bone marrow destruction and were also increased in aplastic anemia patients and correlated closely with progression of AA [6]. Immune and autoimmune responses are regulated by a balance between effectors and regulatory $\mathrm{T}$ cells. Treg as regulatory $\mathrm{T}$ cells with autoimmune tissue injury inhibiting activity, were reduced in AA patients [7].

Numerous strategies have been applied in the treatment of AA including immunosuppression and/or hematopoietic stem-cell transplantation [8]. Immunosuppression has been found effective in producing complete or partial remission in aplastic anemia. Combination of antithymocyte globulin (ATG) with androgens or cyclosporin (CsA) is used for AA patients who are not eligible to bone marrow transplantation due to their age or lacking a matched sibling donor. For younger patients with severe AA and with available compatible bone marrow donors, bone marrow transplantation would be a logical choice. Allogeneic transplant from a matched sibling donor cures the great majority of patients. Although these treatments could alleviate the disease, more attention should be paid to the complications. For immunosuppression, relapse of AA and clonal diseases such as myelodysplasia, leukaemia and paroxysmal nocturnal hemoglobinuria (PNH) are the major concerns [9]. Furthermore, therapeutic agents could accompany with side effects such as anaphylaxis fever, chest pain and diarrhea. For hematopoietic stem-cell transplantation, the type of allograft and the age of the patient are the most important factors affecting the outcome of treatment. These actualities make the transplantation less favorable when compared with immunosuppression as the age of AA patients increases [10].

In 2007, Ohsawa et al. found that hydrogen can protect the brain against ischemia-reperfusion injury and stroke through antioxidant and anti-apoptotic mechanisms [11]. Since then, lots of researches have focused on this astonishing effect of hydrogen. Recent studies either for basic or in clinic revealed that hydrogen inhibited oxidative stress-induced inflammatory tissue injury by down-regulation of cytokines, such as IL-1 $\beta$, IL-6, IL-10, IL-12, tumor necrosis factor- $\alpha$ (TNF- $\alpha$ ) and IFN- $\gamma$, which play critical roles in the development and progression of AA [12-16]. As we found that hydrogen-rich solution could protect mice from lethal acute graft-versus-host disease (GVHD) by promoting the recovery of peripheral blood and regulating serum cytokines levels such as TNF- $\alpha$, IL-2, IL-10 in a GVHD mice [17], we deduce that hydrogen might have therapeutic effects on aplastic anemia which also manifest the similar serum cytokines changes. However, no related experimental findings on the effects of hydrogen in the treatment of aplastic anemia are available up to now. Our results established a strong support for the therapeutic effects of hydrogen on aplastic anemia. 


\section{Cellular Physiology \\ and Biochemistry}

Cell Physiol Biochem 2013;32:549-560

\begin{tabular}{l|l}
\hline DOI: $10.1159 / 000354459$ & (C) 2013 S. Karger AG, Basel
\end{tabular}

Published online: August 30, $2013 \quad$ www.karger.com/cpb

Zhao/Mei/Qian et al.: Hydrogen to Aplastic Anemia

\section{Materials and Methods}

\section{Hydrogen-rich solution production}

$\mathrm{H}_{2}$ was dissolved in physiological saline for $6 \mathrm{~h}$ under high pressure $(0.4 \mathrm{MPa})$ to a supersaturated level using a hydrogen-rich water-producing apparatus produced by our department. The saturated $\mathrm{H}_{2}$ solution was stored under atmospheric pressure at $4^{\circ} \mathrm{C}$ in an aluminium bag with vacuum. Hydrogen-rich solution was freshly prepared every week, which ensured that a concentration of more than $0.6 \mathrm{mM}$ was maintained. Gas chromatography was used to confirm the content of $\mathrm{H}_{2}$ in saline by the method described by Ohsawa et al [11].

\section{Animals}

Male C57BL/6 (8 weeks old) and hybrid CByB6F1 (8 weeks old) mice were obtained from the Second Military Medical University, China in accordance with the Guide for Care and Use of Laboratory Animals published by the US NIH (publication No. 96-01). The animals were housed in individual cages in a temperature-controlled room $\left(28^{\circ}\right)$ with a $12 \mathrm{~h}$ light/dark cycle and food and water were provided $a d$ libitum. All mice were used at 8-12 weeks of age.

\section{Induction of aplastic anemia model}

Inguinal, mesenteric, axillary, lateral axillary and cervical regions lymph nodes (LN) were obtained from C57BL/6 donor mice. LN tissues were processed in a tissue grinder and were disaggregated in 95$\mu \mathrm{m}$ nylon mesh to obtain single cell suspensions. LN cells were washed twice in phosphate-buffered saline (PBS), and then enumerated by light microscopy after Trypan Blue staining for viability. CByB6F1 mice as recipients were irradiated at $5 \mathrm{~Gy}$ TBI at approximately $0.9 \mathrm{~Gy} / \mathrm{min}$ and were injected with $\mathrm{MHC}$-mismatched LN cells through tail veins at $5 \times 10^{6}$ cells/mouse 4 to 6 hours after irradiation $[18,19]$.

\section{Treatment}

Animals were divided into four groups and treated for 28 days as follows: the control group ( $\mathrm{n}=10)$ which was treated with nothing, the radiation group $(n=10)$ was irradiated with 5 Gy TBI at approximately $0.9 \mathrm{~Gy} / \mathrm{min}$ only. Both the AA group $(\mathrm{n}=10)$ and the experimental group $(\mathrm{n}=10)$ were treated as the model of aplastic anemia. While the AA group was intra-peritoneally injected saline $(5 \mathrm{ml} / \mathrm{kg} /$ day) once daily for 28 days, while the experimental group was intra-peritoneally injected hydrogen rich solution $(5 \mathrm{ml} / \mathrm{kg} / \mathrm{day})$ once daily for 28 days.

\section{Body Weight}

During the period of supplement hydrogen-rich solution, all mice were observed and weighted by an electronic scale (GH-202, AND, Japan) on everyday afternoon. The mean body weight was analyzed.

\section{Peripheral Blood}

Blood were collected from the retro-orbital simus/plexus using EDTA-coated blood collection tubes at day 28 after AA model was completed. Red blood cells (RBCs), white blood cells (WBCs), platelet (Plt) and hemoglobin $(\mathrm{Hb})$ were detected by blood cell analyzer (XFA6000Intelligent, Pulang, Nanjing, specific for mice).

\section{Bone marrow nucleated cells and tissue histology}

Mice were killed by cervical dislocation. The contents of the right femur were aspirated into $1.0 \mathrm{ml}$ of DMEM to prepare for a morrow cell suspension. And the marrow cell suspension were diluted 1000 times and counted in optical microscope. The left femur were removed and fixed in $10 \%$ formalin. Femur were sectioned and then stained with Hematoxylin \& Eosin and Terminal Transferase Mediated end Labeling (TUNEL). Stained sections were examined by light microscopy (Eclipse 800, Nikon). TUNEL positive nuclei were stained brown and considered to be apoptotic. TUNEL negative nuclei were stained blue. The mean percentage of apoptotic nuclei for each group was obtained by averaging the results of 6 counting. 


\section{Cellular Physiology and Biochemistry}

Cell Physiol Biochem 2013;32:549-560

\begin{tabular}{l|l}
\hline DOI: $10.1159 / 000354459$ & (C) 2013 S. Karger AG, Basel
\end{tabular}

Published onlıne: August 30, $2013 \quad$ www.karger.com/cpb

Zhao/Mei/Qian et al.: Hydrogen to Aplastic Anemia

Bone marrow clonogenic assay

Bone marrow cells, collected as previously described, were washed, diluted in 30\% FBS-IMDM, and then seeded in Metheoclut-M3001 (Stem Cell Technologies, Vancouver, BC, Canada) for the CFU-GM assay. The Metheoclut-M3001 contains Iscove's methylcellulose (1\%), FBS (15\%), BSA (1\%), bovine pancreatic insulin $(10 \mu \mathrm{g} / \mathrm{ml})$, human transferrin iron-saturated $(200 \mu \mathrm{g} / \mathrm{ml})$, glutamine $(2 \mathrm{mM})$ and GM-CSF $(10 \mathrm{ng} /$ $\mathrm{ml})$.

The clonogenic assay was performed by adding $300 \mathrm{ul}$ of cells $\left(2 * 10^{5} \mathrm{cells} / \mathrm{ml}\right)$ to a $3 \mathrm{ml}$ methylcellulose tube. In order to obtain a triplicate for each dose, $1 \mathrm{ml}$ methylcellulose-cell suspension was seeded in 35 $\mathrm{mm}$ dishes, and the cultures were incubated at $37^{\circ} \mathrm{C}$ in $5 \% \mathrm{CO}_{2}$ for 13 days.

The numbers of CFU-S were evaluated by counting the number of colonies in the spleen on day 13, using Till and McCulloch's method. Briefly, BM cells were harvested and $8 \times 10^{4}$ cells were injected through the tail vein of the recipients that were radiated at 4 Gy before. 13 days after injection of the cells, the mice were killed, and their spleens were removed and fixed in Bouin's solution so that colonies could be better visualized on the surfaces of the spleens.

\section{CD4/CD8 ratio in spleen}

All animals were killed by cervical dislocation and spleens were converted into single-cell suspensions by disaggregated in $95-\mu \mathrm{m}$ nylon mesh. The cells were surface-stained for $30 \mathrm{~min}$ at room temperature by subsequent incubation with anti-feline CD4-PE (diluted 1/25 in FACS buffer) and anti-feline CD8-FITC (diluted 1/17). For each sample, 20,000 cells were analyzed, employing a FACS calibur ${ }^{\mathrm{TM}}$ flow cytometer (Beckman) and the Windows-based EXPOTM32 software, live-gating for lymphocytes in the forward and side scatter.

Enzyme -linked immunosorbent assay for TNF- $\alpha$, IFN-Y, IL-6

Blood were collected from the retro-orbital simus/plexus using blood collection tubes at 4, 14 days after AA model was completed. And then, blood was kept at room temperature for 30 minutes followed by centrifugation at $3000 \mathrm{rpm} / \mathrm{min}$. Serum were removed and stored at $-20^{\circ} \mathrm{C}$. After all samples were collected, the level of TNF- $\alpha$, IFN- $\Upsilon$, and IL- 6 were detected by Enzyme -linked immunosorbent assay (ELISA), employing an ELISA (DENLEY DRAGON Wellscan MK 3, Thermo, Finland) and the Ascent software for Multiskan. All steps were operated as prospectus.

\section{Statistical analysis}

Data were expressed as mean $\pm \mathrm{SD}$. The difference among groups was tested by one-way ANOVA, followed by Scheffe's modified F-test for multiple comparisons using the SPSS 13.0. A value of $\mathrm{P}<0.05$ was considered to be statistically significant.

\section{Results}

\section{Body weight changes}

The body weight curves are given in Fig. 1. The mean value of body weight in each group at the beginning of the study is $18.6 \pm 0.15 \mathrm{~g}$. There was no significant difference among four groups. The body weight increased much faster than that of the AA group during the whole course. At the $28^{\text {th }}$ day, the weight of the experimental group is $21.8 \pm 0.23 \mathrm{~g}$ compared to $20.7 \pm 0.34 \mathrm{~g}$ in AA group, which showed a statistical significance. The average growth is $1.90 \pm 0.25 \mathrm{~g}$ in AA mice and 3.01 $\pm 0.15 \mathrm{~g}$ in experimental group four weeks later $(\mathrm{P}<0.05)$.

\section{Supplemental effects on peripheral blood of AA mice}

To test how AA mice reacted to hydrogen-rich solution in vivo, we evaluated the effect of hydrogen-rich solution on hematopoiesis of mice by the following indicators: RBCs, WBCs, mean Plt and $\mathrm{Hb}$. As shown in Fig. 2, at the $7^{\text {th }}$ day of the research, there was no significant difference in the number of RBC, WBC, Plt and mean $\mathrm{Hb}$ between the AA group and the experimental group $\left(1.35 \pm 0.11 \times 10^{12} / \mathrm{L}\right.$ vs $1.33 \pm 0.12 \times 10^{12} / \mathrm{L}, 1.48 \pm 0.10 \times 10^{9} / \mathrm{L}$ vs $1.47 \pm 0.10 \times 10^{9} / \mathrm{L}, 320 \pm 18 \times 10^{9} / \mathrm{L}$ vs $325 \pm 25 \times 10^{9} / \mathrm{L}, 75 \pm 7.3 \mathrm{~g} / \mathrm{L}$ vs $74 \pm 7 \mathrm{~g} / \mathrm{L}$, respectively). 
Fig. 1. Body weight changes after 28 days. After treatment with hydrogen-rich saline for 28 days, the medicine group has a significantly increase in body weight compare to the AA group. ${ }^{*} \mathrm{P}<0.05$ compared with the AA group at corresponding time-point.. Values are mean \pm SD for 30 mice from each other group.
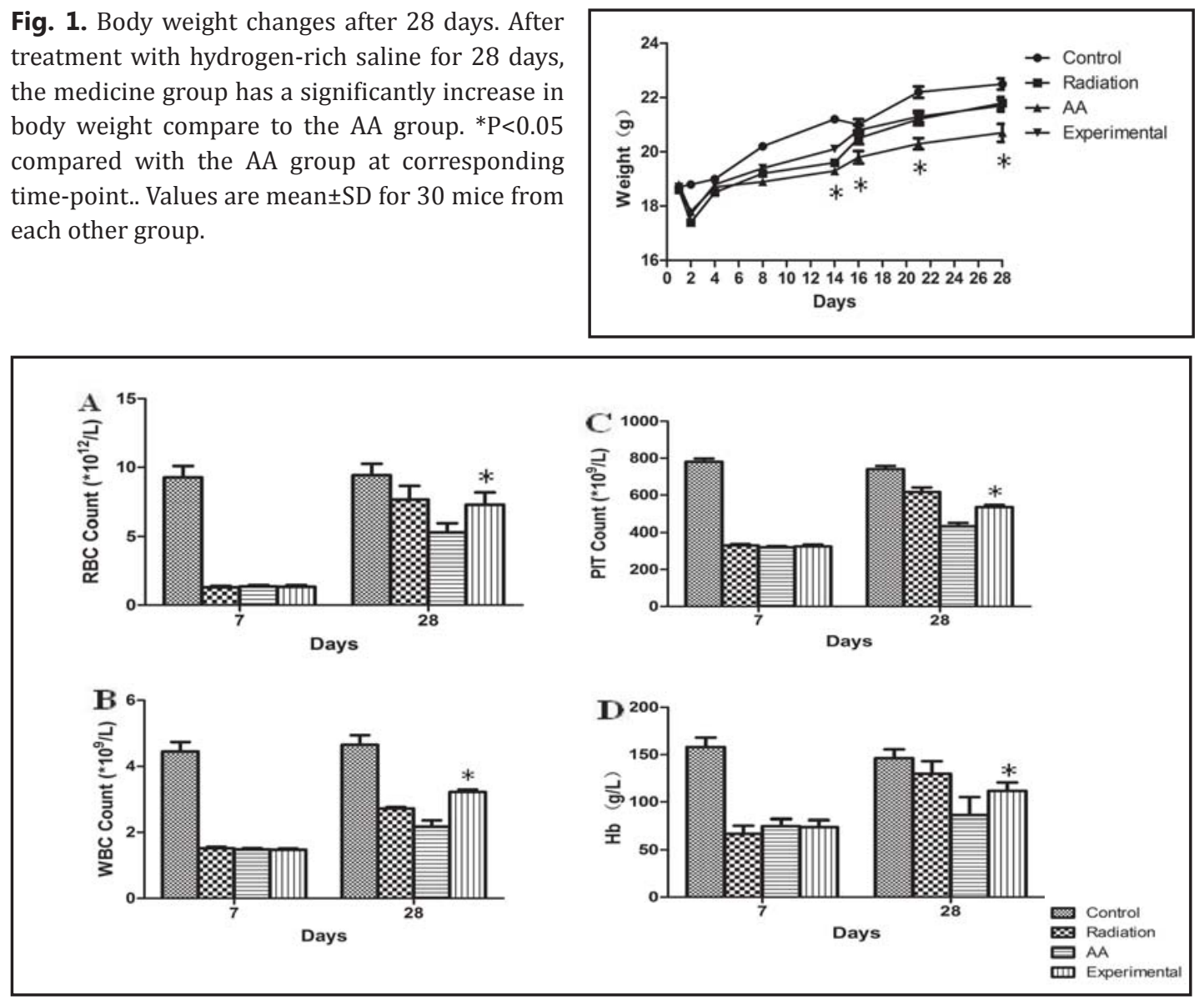

Fig. 2. Effect of hydrogen-rich saline on peripheral blood of AA mice after treatment AA mice with hydrogen-rich saline for 28 days. (A) The number of RBC. (B) The number of WBC. (C) The number of Plt. (D) The content of $\mathrm{HGB}$. ${ }^{*} \mathrm{P}<0.05$ compared with the AA group at corresponding time-point. Values are mean $\pm \mathrm{SD}$ for 30 mice from each other group.

After treated with hydrogen-rich solution for 28 days, the RBC, WBC, Plt counts and mean $\mathrm{Hb}$ concentration of the experimental group all increased significantly compared to the AA group $\left(5.29 \pm 0.68 \times 10^{12} / \mathrm{L}\right.$ vs $7.27 \pm 0.90 \times 10^{12} / \mathrm{L}, 2.18 \pm 0.46 \times 10^{9} / \mathrm{L}$ vs $3.23 \pm 0.18 \times 10^{9} / \mathrm{L}$, $431 \pm 45 \times 10^{9} / \mathrm{L}$ vs $535 \pm 31 \times 10^{9} / \mathrm{L}, 86 \pm 18.8 \mathrm{~g} / \mathrm{L}$ vs $111.7 \pm 8.86 \mathrm{~g} / \mathrm{L} ; \mathrm{P}<0.05$ for all ). All these data showed indicated hydrogen-rich solution played potential role in alleviating AA peripheral blood injuries.

\section{Supplemental effects on Bone Marrow of AA mice}

Bone marrow nucleated cells. The number of BMNCs decreased and the hematopoiesis suppression was induced obviously in both AA group and experimental group. There was no significant difference at day 7 after establishing AA. Compared to AA group, $\mathrm{H}_{2}$-treatment accelerated hematopoietic recovery significantly by increasing the numbers of BMNC. At day 28 after establishing AA, the number of BMNC in the experimental group returned to $8.8 \times 10^{6} \pm 0.82$ /femur, as compared to $4.35 \times 10^{6} \pm 0.81$ /femur in AA group (Fig. 3). Significant difference was also found between the two groups $(\mathrm{P}<0.05)$.

Bone marrow histological analysis. Histological examination of bone marrow also proved that hydrogen-rich solution can accelerate hematopoietic recovery. Fig. 3B shows that at day 7 after establishing AA, both the AA group and the experimental group were hyperemic. While on days 28 , the numbers of bone marrow cells were significantly higher in 


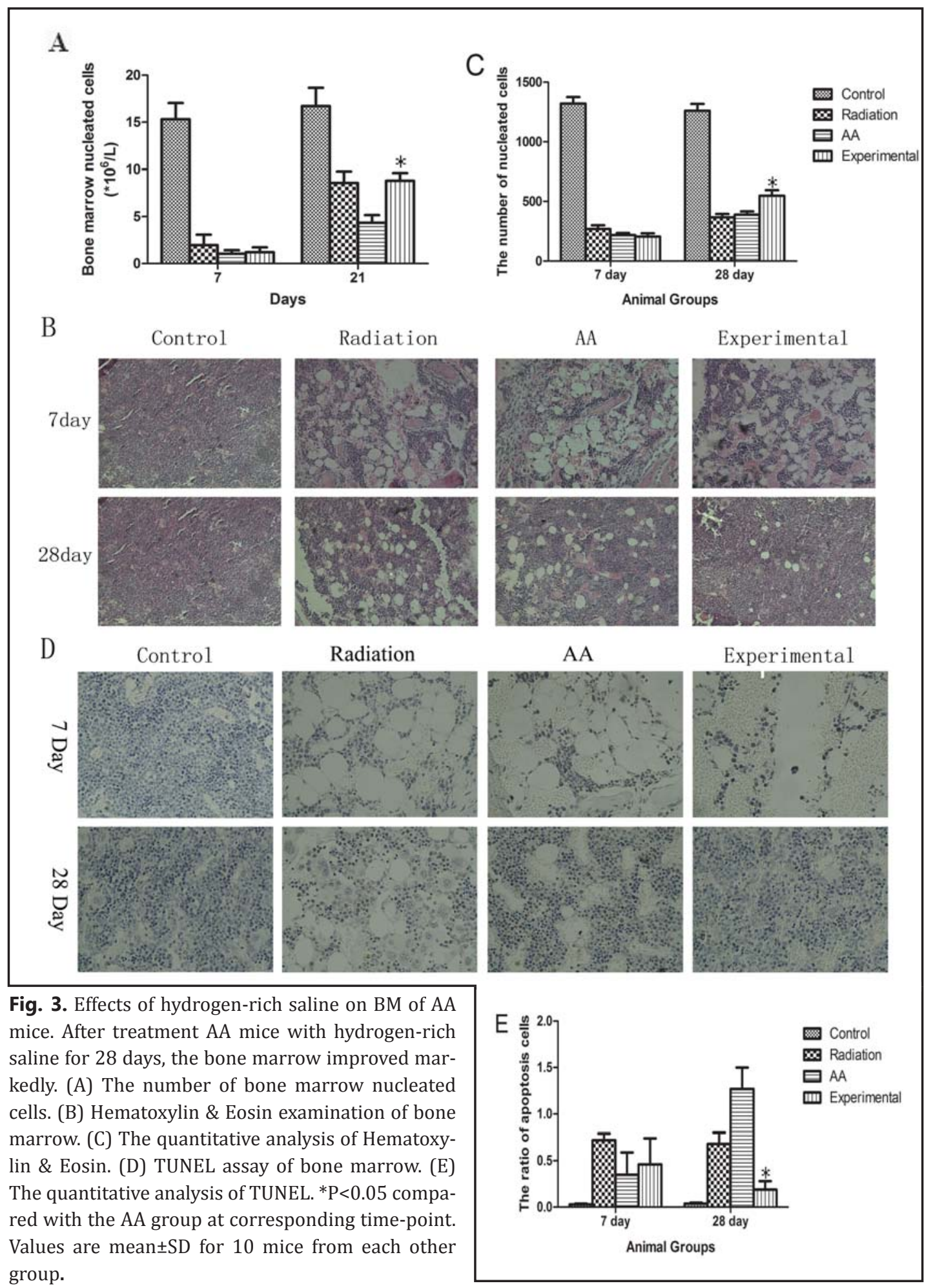

the experimental group than that in the AA group. The data was supported by bone marrow cell counts showed in Fig. 3C.

To investigate whether hydrogen can altered cell apoptosis, we examined cell apoptosis by in situ TUNELassay. The TUNEL results showed that the AA group had more positive cells compared to that in experimental group (Fig. 3D,E). 


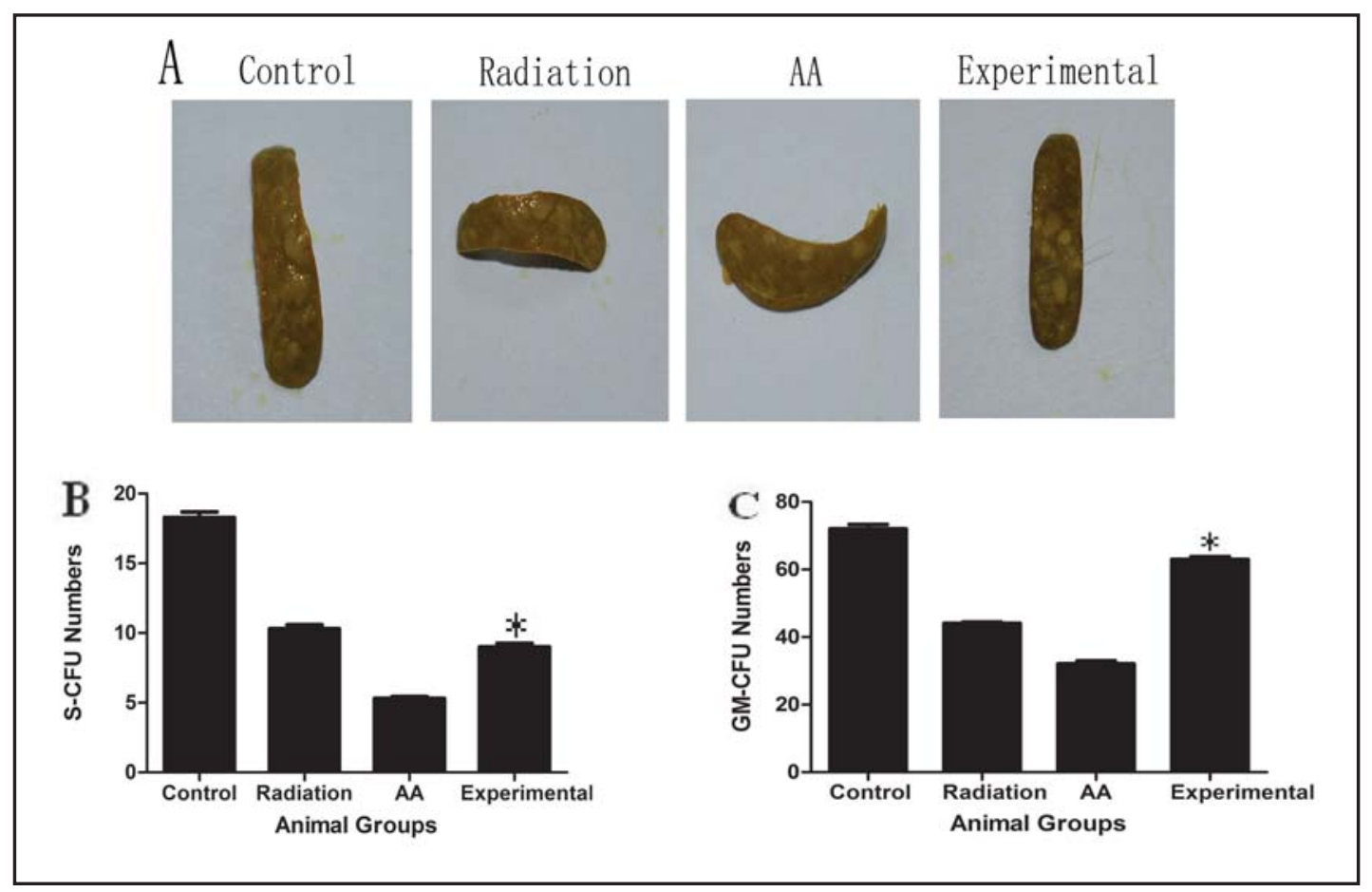

Fig. 4. Effects on primitive hematopoietic progenitors of AA mice. After treatment AA mice with hydrogenrich saline for 28 days, the numbers of hematopoietic progenitors of AA mice were increased markedly. (A) The pictures of CFU-S. (B) The number of CFU-S after injection for 13 days. (C) The number of CFU-GM after incubation for 13 days. ${ }^{*} \mathrm{P}<0.05$ compared with the AA group at corresponding time-point. ${ }^{* *} \mathrm{P}<0.01$ compared with the AA group at corresponding time-point. Values are mean \pm SD for 10 mice from each other group.

Effects on primitive hematopoietic progenitors of AA mice

CFU can exhibits many characteristics of primitive HSCs, such as extensive proliferative capacity, the ability of self-renewal and the capability of generating multiple hemopoietic lineages. As showed in Fig. 4A, B, C, the numbers of CFU-S and CFU-GM in experimental group were apparently higher than that in AA group $(9 \pm 0.5$ vs $5.3 \pm 0.35,73 \pm 2.55$ vs $32.1 \pm 2.76$, $\mathrm{P}<0.05$ for both), which indicated a direct proliferation due to hydrogen-rich solution on committed hematopoietic progenitor cells.

\section{T cell pathophysiology}

The percent of CD4+ and CD8+ were showed in Fig. 5A. Both the numbers of CD4+ and CD8+ changed in AA mice and experimental group, but the situation was improved drastically in experimental group. After 14 days of hydrogen-rich solution treatment, the percentage of CD4+ was increased to $8.31 \%$ in experimental group compared to $3.96 \%$ in AA group. While the percentage of CD8+ was decreased to $4.51 \%$ in experimental group compared to $4.77 \%$ in AA group. The ratio of CD4/CD8 showed in Fig. 5B, the ratio was 1.84 in the experimental group compared to 0.83 in the AA group14 days later.

\section{Detection of TNF- $\alpha$, IFN- $\gamma$, and IL-6}

To characterize the effect of hydrogen on AA, the concentration of TNF- $\alpha /$ IFN- $\gamma / \mathrm{IL}-6$ were measured by ELISA. As shown in Fig. 5C, the average level of TNF- $\alpha$ was much higher in AA group (128.6 $\pm 8.5 \mathrm{pg} / \mathrm{ml})$ and experimental group $(119 \pm 10.4 \mathrm{pg} / \mathrm{ml})$ compared to control group $(45.8 \pm 7.0 \mathrm{pg} / \mathrm{ml})$ at day 4 . However, 10 days later, the concentration of TNF- $\alpha$ in experimental group was far below compared to the AA group $(73.1 \pm 1 \mathrm{pg} / \mathrm{ml}$ vs $114.3 \pm 12.6$ $\mathrm{pg} / \mathrm{ml}, \mathrm{P}<0.05$ ). 


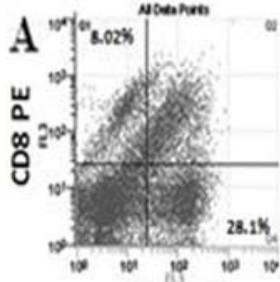

CD4 FITC

Control

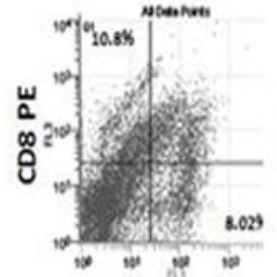

CO4 FITC

Radiation

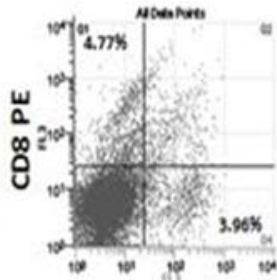

CD4 FITC

$\mathrm{AA}$

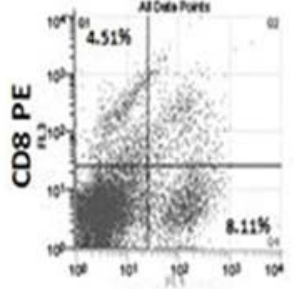

CD4 FITC

Experimental
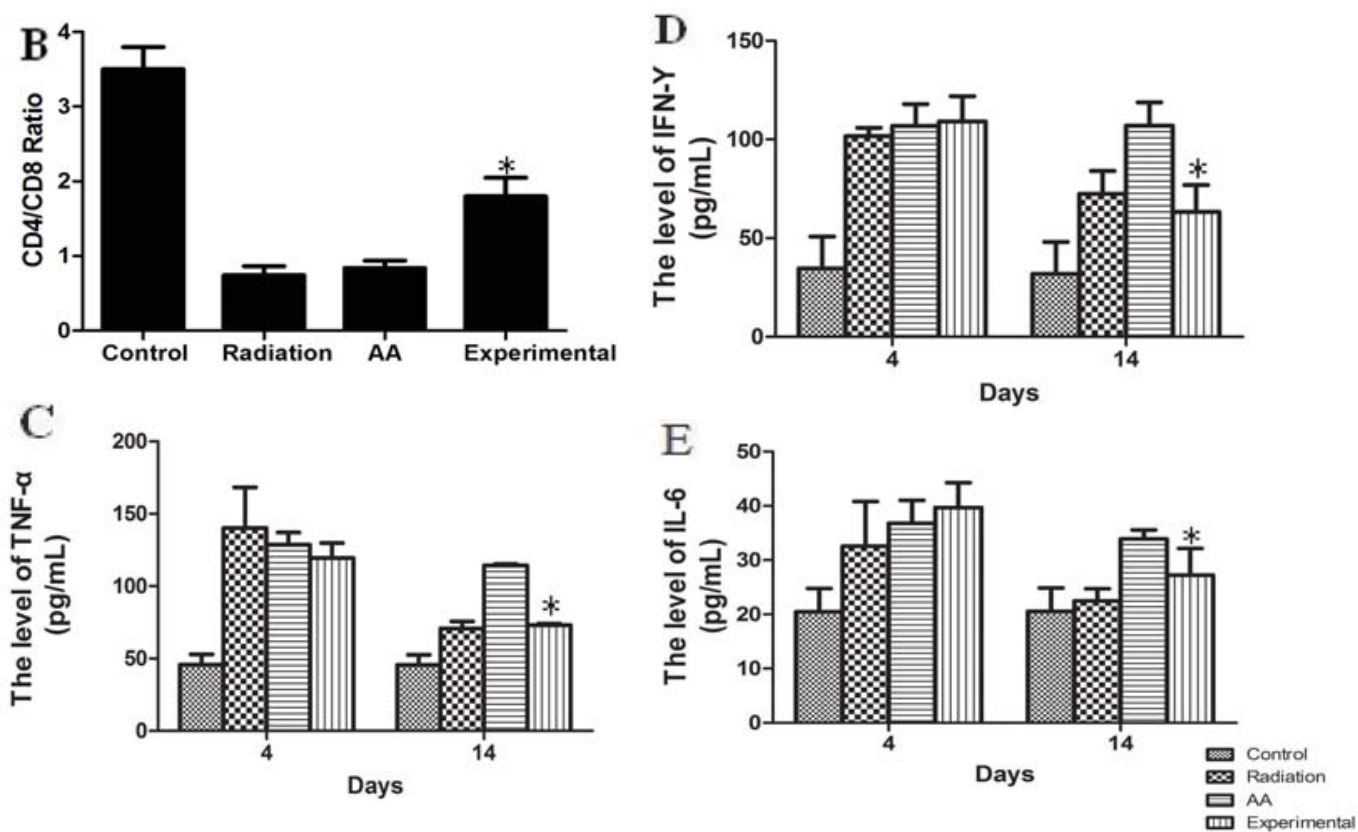

Fig. 5. Effects of hydrogen-rich saline on immune system of AA mice. After treatment AA mice with hydrogen-rich saline for 14 days, the percent of CD4 and CD8 returned to normal level (A). The CD4/CD8 ratio was become to normal (B). The level of TNF- $\alpha$ was decreased (C). The level of IFN- $\Upsilon$ was down-regulated (D). The level of IL- 6 was dropped (E). ${ }^{*} \mathrm{P}<0.05$ compared with the AA group at corresponding time-point. ${ }^{* *} \mathrm{P}<0.01$ compared with the AA group at corresponding time-point. Values are mean $\pm \mathrm{SD}$ for 30 mice from each other group.

Compared to the control group, the average IFN- $\gamma$ level was significantly higher in AA group and experimental group $(34.7 \pm 16.1 \mathrm{pg} / \mathrm{ml}$ vs $107.0 \pm 11.0 \mathrm{pg} / \mathrm{ml}, 109 \pm 12.9 \mathrm{pg} / \mathrm{ml})$ at day 4. After 10 days, the level of IFN- $\gamma$ in experimental group decreased dramatically, while the level of IFN- $\gamma$ in AA group was still high $(63.3 \pm 13.7 \mathrm{pg} / \mathrm{ml}$ vs107.1 $\pm 15.1 \mathrm{pg} / \mathrm{ml}, \mathrm{P}<0.05)$ (Fig. 5D).

The IL-6 level was higher in AA group $(36.8 \pm 4.2 \mathrm{pg} / \mathrm{ml})$ and experimental group $(39.7 \pm 4.6 \mathrm{pg} / \mathrm{ml})$ at day 4 , whereas it was $20.5 \pm 4.3 \mathrm{pg} / \mathrm{ml}$ in control group. After 10 days, the level of IL- 6 in radiation group $(22.5 \pm 2.6 \mathrm{pg} / \mathrm{ml})$ and experimental group $(27.2 \pm 4.9 \mathrm{pg} /$ $\mathrm{ml}$ ) were reduced while the level of IL- 6 in AA group was $33.9 \pm 1.7 \mathrm{pg} / \mathrm{ml}$ (Fig. 5E). There was significant difference between AA group and experimental group $(\mathrm{P}<0.05)$. 


\section{Cellular Physiology and Biochemistry}

Cell Physiol Biochem 2013;32:549-560

DOI: 10.1159/000354459

online: August 30, 201

C) 2013 S. Karger AG, Basel

www.karger.com/cpb

\section{Discussion}

AA is characterized by hypocellular bone marrow resulting from hematopoietic stem cells damages. It results in pancytopenia with risk of severe anemia, major hemorrhage, and life-threatening infections [20]. Laboratory studies and clinical observations have suggested that the pathophysiology of AA is largely mediated by immune dysfunction, in which alterations in T-cell function and cytokine production play critical roles in AA [21]. Therapies, including bone marrow transplantation, anti-thymocyte globulin and/or corticosteroids, etc, have a clinical therapeutic effect in approximately $50 \%$ of AA patients. However, a large portion of patients may fail in responding to the treatments or relapse after the treatment [22]. Recently, we found that hydrogen-rich solution can protect the immune system and accelerate the recovery of immunodeficiency induced by irradiation [23]. Meanwhile, our research determined that hydrogen can protect mice from GVHD by regulating TNF- $\alpha$, IL-2, IL-10 [17]. Hydrogen was also demonstrated to be able to down-regulate levels of various cytokines, including TNF- $\alpha$, IFN- $\gamma$, IL-1, IL-6, IL-12 in different models [24-26]. These cytokines play important roles in AA. Meantime, hydrogen is produced by colonic bacteria in our body continuously and has no side effects to human body [27]. This provides us some clue for $\mathrm{H}_{2}$ as an ideal drug for AA.

The peripheral blood decrease is the evidence of bone marrow failure termed as "residual injury" [28]. The values of hematologic parameters in AA patients are far lower than normal people. The improvement of peripheral blood parameters is an indicator that AA is relieved after therapies. In our study, AA mice which were treated with hydrogen-rich solution appear to be more sensitive to hydrogen-rich solution. The data demonstrated that the hematological parameters of experimental group are much higher than that of the values observed in AA mice. This result is consistent with other observations that can accelerate rehabilitation of hematological parameters.

Bone marrow which consists of hematopoietic stem cells (HSCs), mesenchymal stem cells (MSCs), and endothelial progenitor cells is considered as the major hematopoietic tissue. Damages of bone marrow are considered severe during the development of AA. The cavum ossis was filled with a great amount of fat cells and plasma cells [29]. As a result, the hematopoietic capacity is diminished. In the present study, bone marrow cell counting and bone marrow histological examination represent the different degrees of damages, which reflected a faster recovery speed of bone marrow in experimental group. Furthermore, CFU-S and CFU-GM are good indicators of cell viability of bone marrow. Either of them could be a reflection of the status of hematopoietic cells. In our research, CFU-S and CFU-GM were detected to evaluate the sensitivity of hematopoietic cells to hydrogen-rich solution in bone marrow. Hematopoietic cells from the AA mice were highly sensitive to hydrogenrich solution. The quantities of CFU-S and CFU-GM in experimental group are much higher than AA group. All these results showed that hydrogen-rich solution can improve the bone marrow microenvironment, promote the nucleated cells proliferation, and increase colony formation.

AA is an immune-mediated disease. The disorder of immune system especially $\mathrm{T}$ cells plays an important role in the development of AA. Antigens are presented to T cells by antigen-presenting cells, which trigger $\mathrm{T}$ cells activation and proliferation. Activated T cells were differentiated into CD4 ${ }^{+}$Th1/Th2/Th17/Treg cells and CD8 ${ }^{+}$cells. All those cells play crucial roles in aplastic anemia [30]. On one hand, Th1 cells can secrete a variety of immune molecules including IFN- $\gamma$, TNF- $\alpha$ directly; On the other hand, Th1 cells can promote the activation of NK cells, CD8+T cells, and macrophage cells which could secrete various of cytokine including IFN- $\gamma$, TNF- $\alpha$, IL-6, IL-2 and mediate apoptosis [31]. Abnormal proliferation of $\mathrm{CD}^{+} \mathrm{T}$ cells induces the imbalance of the ratio of CD4/CD8. IFN- $\gamma$ and TNF- $\alpha$ up-regulate other $\mathrm{T}$ cellular receptors and also the Fas receptor. Increased IL-2 leads to the expansion of T cells. Activation of Fas receptors by the Fas ligand induces the apoptosis of target cells. All those cytokine secreting cells compose a cytokine network to destruct stem cells as well as mesenchymal stem cells and endothelial progenitor cells. As a result, stem 


\section{Cellular Physiology and Biochemistry}

Cell Physiol Biochem 2013;32:549-560

\begin{tabular}{l|l}
\hline DOI: $10.1159 / 000354459$ & C) 2013 S. Karger AG, Basel
\end{tabular}

Published online: August 30, 2013 www.karger.com/cpb

Zhao/Mei/Qian et al.: Hydrogen to Aplastic Anemia

cells are significantly impaired and lose the capacity of proliferation and differentiation. The present study showed that $\mathrm{CD} 4^{+} / \mathrm{CD}^{+}$cells in AA mice even returned to normal after consecutive treatment with hydrogen-rich solution for 28 days. This is consistent with the results of other AA researches $[19,32,33]$. Meanwhile, we found that IFN- $\gamma$, TNF- $\alpha$, and IL-6 were down-regulated after treatment with hydrogen-rich solution 14 days later. All together, we deduced that hydrogen-rich solution may heal AA by mediating immune system. In this study, we found that hydrogen-rich solution could treat aplastic anemia effectively on mice model with a most possible mechanism by immune system modulating. Hydrogenrich solution can also ameliorate bone marrow microenvironment damages, improve stem cells differentiation and proliferation. However, the direct molecular target of $\mathrm{H} 2$ has not been determined. Based on previous studies and our data, the possible mechanism of H2 on the therapy of AA might be as follows. Firstly, it was reported that $\mathrm{H} 2$ inhibited NF- $\mathrm{kB}$ activation, which causes a transcriptional up-regulation of inflammatory cytokines, such as TNF- $\alpha$, IL-6, IFN- $\gamma$ etc $[24,34,35]$. These cytokines was also found decreased in the H2 treated groups in our experiment, indicating NF- $\mathrm{\kappa B}$ as a possible target for the regulating effect of $\mathrm{H} 2$ on the cytokines microenvironment. Secondly, it has been found that $\mathrm{H} 2$ can induce heme oxygenase-1 (HO-1) expression, in which way act as a strong antioxidant [36]. HO-1 mediated the antioxidant effect many factors, such as IL-10. HO-1 expression also affects cytokines secretion related to T cell modulation [37]. So $\mathrm{H} 2$ might effect on cells and in tissues through regulating the expression and activity of HO-1. Thirdly, our data from the microarray analysis showed that $\mathrm{H} 2$ treatment resulted in up-regulation of CCL2, also referred as inducible cytokine. CCL2 also could induce many key cytokines and also could be regulated by inflammatory cytokines. The microenvironment of cytokines in vivo is highly regulated and very complicated. Although $\mathrm{H} 2$ has been found to affect apoptosis signalling pathway, FceRI-associated signalling pathway, inhibit the LPS induced NO production in macrophages, the direct target has not been found yet. So the underlying mechanism of the effect of $\mathrm{H} 2$ on AA still needs to be clarified by future studies.

Besides therapeutic effects, safety is another important requirement for applying hydrogen in aplastic anemia. To our knowledge, hydrogen can be produced by bacteria and circulate in the body [38], and the reaction between $\mathrm{H} 2$ and $\bullet \mathrm{OH}$ produces water [39]. It is physiologically safe for human to ingest $\mathrm{H}_{2}$ at a relatively low concentration [40]. Dissolving $\mathrm{H}_{2}$ in physiological saline has no risk of flammability or explosion and is easy to apply.

\section{Conclusion}

In conclusion, this study showed that hydrogen-rich solution could treat aplastic anemia effectively on mice model through immune modulating mechanism. Hydrogenrich solution can ameliorate bone marrow microenvironment damages, improve stem cells differentiation and proliferation. However, a better understanding of the molecular, cellular and physiological mechanisms related to the improvement of AA by hydrogen-rich solution may request further full-scale studies.

\section{Conflict of Interest}

The author has no conflict of interest to disclose.

\section{Acknowledgements}

This work was supported by a grant from the National Natural Science Foundation of China (No. 81072241) and by a grant from Natural Science Foundation of Shanghai, China (No.11ZR1446400). 


\section{Cellular Physiology and Biochemistry}

Cell Physiol Biochem 2013;32:549-560

\begin{tabular}{l|l}
\hline DOI: $10.1159 / 000354459$ & (C) 2013 S. Karger AG, Basel
\end{tabular}

Published online: August 30, $2013 \quad$ www.karger.com/cpb

Zhao/Mei/Qian et al.: Hydrogen to Aplastic Anemia

\section{References}

1 Champlin RE, Perez WS, Passweg JR, Klein JP, Camitta BM, Gluckman E, Bredeson CN, Eapen M, Horowitz MM: Bone marrow transplantation for severe aplastic anemia: a randomized controlled study of conditioning regimens. Blood 2007;109:4582-4585.

2 Metcalf D: A promising new treatment for refractory aplastic anemia. N Engl J Med 2012;367:74-75.

- 3 Ge M, Zheng Y, Li X, Lu S, Li H, Chen F, Chen D, Shao Y, Shi J, Feng S: Differential expression profile of Th1/Th17/Th2-related chemokines and their receptors in patients with acquired bone marrow failure syndromes. Hum Immunol 2012; DOI:10.1016/j.humimm.2012.11.001.

-4 Van Coppernolle S, Verstichel G, Timmermans F, Velghe I, Vermijlen D, De Smedt M, Leclercq G, Plum J, Taghon T, Vandekerckhove B, Kerre T: Functionally mature CD4 and CD8 TCRalphabeta cells are generated in OP9-DL1 cultures from human CD34+ hematopoietic cells. J Immunol 2009;183:4859-4870.

5 Tang Y, Desierto MJ, Chen J, Young NS: The role of the Th1 transcription factor T-bet in a mouse model of immune-mediated bone-marrow failure. Blood 2010;115:541-548.

6 Platanias LC: Abnormalities in Th17 T cells in aplastic anemia. Blood 2010;116:4039-4040.

7 Yang YW, Zheng ZY, Yao HZ: [Recent progress of study on imbalance of Th17/Treg cells in aplastic anemia]. Zhongguo Shi Yan Xue Ye Xue Za Zhi 2012;20:214-218.

8 Bacigalupo A: Treatment strategies for patients with severe aplastic anemia. Bone Marrow Transplant 2008;42 Suppl 1:S42-S44.

9 Young NS, Bacigalupo A, Marsh JC: Aplastic anemia: pathophysiology and treatment. Biol Blood Marrow Transplant 2010;16:S119-125.

- 10 Schrezenmeier H, Passweg JR, Marsh JC, Bacigalupo A, Bredeson CN, Bullorsky E, Camitta BM, Champlin RE, Gale RP, Fuhrer M, Klein JP, Locasciulli A, Oneto R, Schattenberg AV, Socie G, Eapen M: Worse outcome and more chronic GVHD with peripheral blood progenitor cells than bone marrow in HLA-matched sibling donor transplants for young patients with severe acquired aplastic anemia. Blood 2007;110:1397-1400.

11 Ohsawa I, Ishikawa M, Takahashi K, Watanabe M, Nishimaki K, Yamagata K, Katsura K, Katayama Y, Asoh S, Ohta S: Hydrogen acts as a therapeutic antioxidant by selectively reducing cytotoxic oxygen radicals. Nat Med 2007;13:688-694.

12 Zheng X, Mao Y, Cai J, Li Y, Liu W, Sun P, Zhang JH, Sun X, Yuan H: Hydrogen-rich saline protects against intestinal ischemia/reperfusion injury in rats. Free Radic Res 2009;43:478-484.

13 Qin ZX, Yu P, Qian DH, Song MB, Tan H, Yu Y, Li W, Wang H, Liu J, Wang Q, Sun XJ, Jiang H, Zhu JK, Lu W, Huang L: Hydrogen-rich saline prevents neointima formation after carotid balloon injury by suppressing ROS and the TNF-alpha/NF-kappaB pathway. Atherosclerosis 2012;220:343-350.

14 Li H, Zhou R, Liu J, Li Q Zhang J, Mu J, Sun X: Hydrogen-rich saline attenuates lung ischemia-reperfusion injury in rabbits. J Surg Res 2012;174:e11-16.

15 Kasuyama K, Tomofuji T, Ekuni D, Tamaki N, Azuma T, Irie K, Endo Y, Morita M: Hydrogen-rich water attenuates experimental periodontitis in a rat model. J Clin Periodontol 2011;38:1085-1090.

-16 Cardinal JS, Zhan J, Wang Y, Sugimoto R, Tsung A, McCurry KR, Billiar TR, Nakao A: Oral hydrogen water prevents chronic allograft nephropathy in rats. Kidney Int 2010;77:101-109.

17 Qian L, Mei K, Shen J, Cai J: Administration of Hydrogen-Rich Saline Protects Mice From Lethal Acute GraftVersus-Host Disease (aGVHD). Transplantation 2013;95:658-662.

18 Liu Z, Sun H, Liu W, Luo X, He L, Xu H. Expression of CD28 and CTLA4 on T cells in bone morrow of immune-mediated aplastic anemia mice. J Huazhong Univ Sci Technolog Med Sci 2005;25:508-509, 515.

19 de Latour RP, Visconte V, Takaku T, Wu C, Erie AJ, Sarcon AK, Desierto MJ, Scheinberg P, Keyvanfar K, Nunez O, Chen J, Young NS: Th17 immune responses contribute to the pathophysiology of aplastic anemia. Blood 2010;116:4175-4184.

20 Alter BP, Rosenberg PS: Granulocyte colony-stimulating factor and severe aplastic anemia. Blood 2007;109:4589; author reply 4589-4590.

21 Young NS, Scheinberg P, Calado RT: Aplastic anemia. Curr Opin Hematol 2008;15:162-168.

22 Young NS: Pathophysiologic mechanisms in acquired aplastic anemia. Hematology Am Soc Hematol Educ Program 2006:72-77.

23 Yang Y, Li B, Liu C, Chuai Y, Lei J, Gao F, Cui J, Sun D, Cheng Y, Zhou C, Cai J: Hydrogen-rich saline protects immunocytes from radiation-induced apoptosis. Med Sci Monit 2012;18:BR144-148. 


\section{Cellular Physiology and Biochemistry}

Cell Physiol Biochem 2013;32:549-560

\begin{tabular}{l|l}
\hline DOI: $10.1159 / 000354459$ & (c) 2013 S. Karger AG, Basel
\end{tabular}

Zhao/Mei/Qian et al.: Hydrogen to Aplastic Anemia

24 Yu YS, Zheng H: Chronic hydrogen-rich saline treatment reduces oxidative stress and attenuates left ventricular hypertrophy in spontaneous hypertensive rats. Mol Cell Biochem 2012;365:233-242.

-25 Zhang Y, Sun Q, He B, Xiao J, Wang Z, Sun X: Anti-inflammatory effect of hydrogen-rich saline in a rat model of regional myocardial ischemia and reperfusion. Int J Cardiol 2011;148:91-95.

26 Qiu X, Li H, Tang H, Jin Y, Li W, YuSun, PingFeng, Sun X, Xia Z: Hydrogen inhalation ameliorates lipopolysaccharide-induced acute lung injury in mice. Int Immunopharmacol 2011;11:2130-2137.

27 Levitt MD: Production and excretion of hydrogen gas in man. N Engl J Med 1969;281:122-127.

-28 Pugsley CA, Forbes IJ, Morley AA: Immunologic abnormalities in an animal model of chronic hypoplastic marrow failure induced by busulfan. Blood 1978;51:601-610.

29 Kanamaru A, Hara Y: [Pathophysiology of stem cells in aplastic anemia (2)]. Rinsho Ketsueki 1976;17:474477.

- 30 He GS, Shao ZH, He H, Liu H, Fu R, Bai J, Shi J, Cao YR, Tu MF, Sun J, Jia HR: [Changes of subsets of DC1 in the bone marrow of severe aplastic anemia patients]. Zhonghua Xue Ye Xue Za Zhi 2004;25:649-652.

-31 Young NS, Calado RT, Scheinberg P: Current concepts in the pathophysiology and treatment of aplastic anemia. Blood 2006;108:2509-2519.

-32 Thiam D, Diakhate L, Niang/Ndiaye M: [CD4+ and CD8+ lymphocyte subpopulations in bone marrow deficiency anemias]. Dakar Med 1989;34:83-87.

-33 Chan EY, Chiu EK, So MK, Lie AK, Chan TK: Peripheral blood lymphocyte subsets after allogeneic bone marrow transplantation: reconstitution and correlation with the occurrence of acute graft-versus-host disease. Asian Pac J Allergy Immunol 1994;12:117-123.

-34 Song G, Tian H, Liu J, Zhang H, Sun X, Qin S: H2 inhibits TNF-alpha-induced lectin-like oxidized LDL receptor-1 expression by inhibiting nuclear factor kappaB activation in endothelial cells. Biotechnol Lett 2011;33:1715-1722.

- 35 Huang CS, Kawamura T, Peng X, Tochigi N, Shigemura N, Billiar TR, Nakao A, Toyoda Y: Hydrogen inhalation reduced epithelial apoptosis in ventilator-induced lung injury via a mechanism involving nuclear factorkappa B activation. Biochem Biophys Res Commun 2011;408:253-258.

36 Buchholz BM, Masutani K, Kawamura T, Peng X, Toyoda Y, Billiar TR, Bauer AJ, Nakao A: Hydrogenenriched preservation protects the isogeneic intestinal graft and amends recipient gastric function during transplantation. Transplantation 2011;92:985-992.

- $37 \mathrm{Hu}$ AP, Du JM, Li JY, Liu JW: Oridonin promotes CD4+/CD25+ Treg differentiation, modulates Th1/Th2 balance and induces HO-1 in rat splenic lymphocytes. Inflamm Res 2008;57:163-170.

- 38 Reth M: Hydrogen peroxide as second messenger in lymphocyte activation. Nat Immunol 2002;3:11291134.

-39 Labiche LA, Grotta JC: Clinical trials for cytoprotection in stroke. NeuroRx 2004;1:46-70.

40 Dole M, Wilson FR, Fife WP: Hyperbaric hydrogen therapy: a possible treatment for cancer. Science 1975;190:152-154. 